\title{
TURNOVER INTENTION AND JOB SATISFACTION AMONG QUANTITY SURVEYORS
}

\author{
Tan Chin Keng ${ }^{1 *}$, Nik Nur Azirah Mohamed Nor ${ }^{1}$, Yeoh Kah Ching ${ }^{2}$ \\ ${ }^{1}$ Department of Quantity Surveying, Kulliyyah of Architecture \& Environmental Design \\ International Islamic University Malaysia, Jalan Gombak, 53100 Kuala Lumpur, Malaysia \\ ${ }^{2}$ Department of Business and IT, New Era University College, Jalan Bukit, 43000 Kajang, Malaysia
}

(Received: July 2018 / Revised: September 2018 / Accepted: December 2018)

\begin{abstract}
Within the framework of human resource management, this study focuses on the issues of turnover intention and job satisfaction in the context of quantity surveying firms. Turnover intention leads to actual turnover. Several factors have been identified to cause turnover intention. Quantity surveyors are among the key players in construction projects. A quantity surveyor is involved in financial and contractual matters from the initiation stage to the completion of construction. In relation to the technical employees of quantity surveying firms, the objectives of this research are: (1) to determine whether these employees have turnover intention; and (2) to determine their level of job satisfaction. The data for this study were collected through a questionnaire survey. The scope of the study is limited to technical staff in quantity surveying firms in Malaysia. A total of 600 questionnaires were distributed to quantity surveyors in these firms, and 183 responses were received within the given period of time. Thus, the response rate for this study is $30.5 \%$. This study found that $38.8 \%$ of respondents intend to quit their current organizations. This percentage is considered high and impacts the staff stability of the firms. Turnover intention might be related to job dissatisfaction; the majority of respondents were not satisfied with most of the items in the constructs of opportunities and rewards, specifically, the salaries, bonuses, benefits, and promotion opportunities provided by the firms. In addition, the majority of the respondents expressed their dissatisfaction with the opportunities provided by their firms to participate in work-related decisions and suggestions.
\end{abstract}

Keywords: Job satisfaction; Quantity surveyor; Turnover intention

\section{INTRODUCTION}

The issue of employee turnover is widely discussed in the literature on organizational behavior. According to Sun (2011), employee turnover is the degree of individuals that quit membership of an organization. Alam (2012) explained that turnover occurs when employees leave their jobs after they have turnover intention. According to Tett and Meyer (1993) and Ali (2008), turnover intention is the willingness of an employee to leave an organization. It is also referred to as behavioral intention to quit an organization.

Turnover intention leads to actual turnover. Several factors have been identified to cause turnover intention. Martin (2010) listed the availability of promotions and career development, the prospect of higher pay, interpersonal conflicts with colleagues, poor human resources

\footnotetext{
*Corresponding author's email: tckeng@iium.edu.my, Tel. +60-19-2544321, Fax. +60-3-61964864 Permalink/DOI: https://doi.org/10.14716/ijtech.v9i8.2760
} 
policies, and personal reasons as some of these factors. Most studies, including those of Nankervis et al. (2005), Samad (2006), Ali (2008), Alam (2012), and Chatzoglou et al. (2011), have found that job satisfaction affects employees' intention to leave an organization. According to Chatzoglou et al. (2011), job satisfaction is defined as an employee's feelings towards his or her job. Alam (2012) added that job satisfaction is an employee's emotion towards and evaluation of their job. Similarly, Puvada and Rao (2012) referred to job satisfaction as an employee's set of emotional feelings about his or her work and organization, and Habib et al. (2010) described job satisfaction as a positive feeling toward an individual's job and experiences.

Quantity surveyors are among the key players involved in a construction project (Rabie \& Riad, 2011). Hee and Ling (2011) described quantity surveyors as professionals involved in the procurement, cost, and contract management processes associated with construction projects. According to Nkado and Meyer (2001), a quantity surveyor is involved in financial and contractual matters from the initiation stage to the completion of construction. This study is concerned with job satisfaction and turnover intention among quantity surveyors. In relation to the technical employees of quantity surveying firms, the objectives of this research are as follows: (1) To determine whether the employees have turnover intention; and (2) To determine the employees' level of job satisfaction.

\section{LITERATURE REVIEW}

Human resources are considered the most valuable assets in an organization that play a key role in its success; according to Ghayyur and Jamal (2012), human resources play an important role in the development of capital in organizations. Arham et al. (2011) explained that failure to manage human resources creates problems within an organization that lead to absenteeism, turnover, and so on. For that reason, employees tend to find alternatives to leave the organization. According to Saeed et al. (2014), high turnover rates are not good for organizations because costs is incurred when employees decide to leave their jobs due to the need for replacement, recruitment, and selection of new employees. It is thus crucial for all organizations to effectively manage their human resources in order to keep them from leaving and causing the organizations to incur costs.

Ali (2008) and Mathis and Jackson (2002) defined employee turnover as voluntarily leaving an organization. Stone (2008) defined turnover as a process in which employees quit their current jobs and must be replaced by new employees, while Martin (2010) stated that turnover describes the percentage of employees leaving an organization. According to Nankervis et al. (2005), turnover involves the movement of human resources in an organization.

Employee turnover happens when an employee intends to leave his or her current organization because the employee has found another organization. According to Glissmeyer et al. (2008), Ali (2008), and Aydogdu and Askigil (2011), turnover intention refers to the attitude that causes an individual to want to leave an organization. Similarly, according to Ghayyur and Jamal (2012) and Alam and Mohammad (2010), turnover is based on an intention to voluntarily quit from an organization. Summarizing the above research, turnover happens when employees leave their organization, and turnover intention describes employee's desire to quit their present job and aim to find another job in the future.

Job satisfaction is one of the factors that affects turnover intention. Wolf (1970) claims that job satisfaction impacts one's behavioral intention to quit a job, and dissatisfaction with a job may cause employees to search for other alternatives. Ali (2008) also found that dissatisfaction with the salary of a job increases the rate of turnover intention. Greater job satisfaction reduces one's intention to leave an organization; according to Mbah and Ikemefuna (2012), job satisfaction 
determines an employee to stay or leave an organization. Employees who have a high level of job satisfaction will have a positive attitude towards their work, which means that they will stay at their jobs longer and not quit. Therefore, an increase in job satisfaction reduces employees turnover.

Many studies have been conducted using different approaches to identify the relationship between job satisfaction and turnover intention. Examining the construction industry, Sun (2011) found that job satisfaction, which is affected by promotions and pay, has a significant impact on construction engineers' turnover intentions. According to Mbah and Ikemefuna (2012), satisfaction with the nature of the job, supervision, and pay is negatively related to turnover intention, and the higher employees' satisfaction with the nature of their work, the lower their chances of having turnover intention. In other words, if an employee feels satisfied, then he or she will stay at an organization longer. Chatzoglou et al. (2011) claimed that there is a significant negative relation between turnover and job satisfaction, which is affected by collaboration with colleagues, the work itself, promotions, the quality of supervision, and salary; a high level of job satisfaction reduces the rate of employees that want to leave an organization. When employees feel satisfied, they will feel positive and loyal to their organization, and therefore, they will stay longer at the organization. Samad (2006) also found that job satisfaction is negatively and significantly related to turnover intention, and Rahman et al. (2008) revealed that job satisfaction based on salary, the nature of work, and supervision has negative effects on turnover intention. Similarly, Ali (2008) mentioned that there is a significant negative association between facets of job satisfaction, including salary, and turnover intention, and Randhawa (2007) mentioned that there is a significant negative correlation between job satisfaction and turnover intention. In other words, higher job satisfaction will decrease an employee's intention to quit from an organization. Like the other studies, Aydogdu and Asikgil (2011) found that turnover intention has a significant and negative relationship with job satisfaction based on salary and supervision. According to Mahdi et al. (2012), there is a relationship between job satisfaction and employees' turnover intention based on working conditions, co-workers, supervion, and the value of work. Ucho et al. (2012) also argued that job satisfaction is negatively related to turnover intention, and Gillet et al. (2012) mentioned that lower satisfaction increases the rate of turnover intention. Further, Yucel (2012) found a relationship between job satisfaction and turnover intention, while Matz et al. (2013) indicated that there is relationship between job satisfaction and turnover intention based on communication and co-workers. Salleh et al. (2012) achieved the same findings regarding job satisfaction and turnover intention: job satisfaction based on work and salary is negatively related to turnover intention. Gamage and Buddhika (2013) also found a significant negative relationship between job satisfaction based on the supervisor, variety in the job, and co-workers and intention to leave. Tnay et al. (2013) claimed that there is a significant relationship between job satisfaction based on salary and turnover intention. Rizwan and Mukhtar (2014) found that employees' satisfaction with their salary, promotion opportunities, workplace environment, and employee empowerment has a significant relationship on turnover intention.

In summary, most of the studies mentioned in the above literature review showed that job satisfaction influences turnover intention among employees; higher levels of job satisfaction decrease the intention to quit an organization. The more satisfied an employee feels with his or her job, the less they will feel they must leave the organization.

\section{RESEARCH METHODOLOGY}

Data for this study were collected through a questionnaire survey. A total of 600 questionnaires were distributed to quantity surveyors in quantity surveying firms in Klang Valley in Malaysia. The addresses of the quantity surveying firms were obtained from the Board of Quantity 
Surveying Malaysia (BQSM). The survey requested that quantity surveyors provide their demographic information, state whether they intent to quit their current jobs, and answer a list of questions regarding job satisfaction.

\section{RESULTS AND DISCUSSION}

From the 600 questionnaires that were distributed randomly to the target respondents, a total of 183 responses were received within the given period of time. Thus, the response rate for this study is $30.5 \%$.

Regarding intention to quit the current job, $61.2 \%$ respondents did not have any intention to quit their current organizations, while $38.8 \%$ of respondents had an intention to quit their current organizations.

As for job satisfaction, the survey questions were designed to determine the quantity surveyors' level of job satisfaction based on the constructs of job satisfaction identified in the literature review. These constructs are as follows:

1) Opportunities and rewards

2) Nature of the work

3) Working relationship with one's immediate superior

4) Organizational factors

5) Social interaction

6) Attitude towards work

Data regarding job satisfaction are tabulated based on the above constructs in Tables 1-6.

Table 1 Level of job satisfaction (Construct: opportunities and rewards)

\begin{tabular}{|c|c|c|c|c|c|c|c|c|c|c|c|c|c|}
\hline \multirow{2}{*}{$\begin{array}{c}\text { Question } \\
\text { No. }\end{array}$} & \multirow[t]{2}{*}{ Questions } & \multicolumn{2}{|c|}{$\begin{array}{l}\text { Strongly } \\
\text { Disagree }\end{array}$} & \multicolumn{2}{|c|}{ Disagree } & \multicolumn{2}{|c|}{ Neutral } & \multicolumn{2}{|c|}{ Agree } & \multicolumn{2}{|c|}{$\begin{array}{l}\text { Strongly } \\
\text { Agree }\end{array}$} & \multicolumn{2}{|c|}{$\begin{array}{c}\text { Total Agree + } \\
\text { Strongly Agree }\end{array}$} \\
\hline & & No. & $\%$ & No. & $\%$ & No. & $\%$ & No. & $\%$ & No. & $\%$ & No. & $\%$ \\
\hline 1 & $\begin{array}{l}\text { I am satisfied with the } \\
\text { salary I am paid }\end{array}$ & 1 & 0.5 & 31 & 16.9 & 80 & 43.7 & 64 & 35.0 & 7 & 3.8 & 71 & 38.8 \\
\hline 2 & $\begin{array}{l}\text { I am satisfied with the } \\
\text { chances given to me for } \\
\text { self-advancement }\end{array}$ & 2 & 1.1 & 8 & 4.4 & 54 & 29.5 & 109 & 59.6 & 10 & 5.5 & 119 & 65.1 \\
\hline 3 & $\begin{array}{l}\text { I am satisfied with the } \\
\text { recognition I received for } \\
\text { good achievement }\end{array}$ & 1 & 0.5 & 11 & 6.0 & 78 & 42.6 & 89 & 48.6 & 4 & 2.2 & 93 & 50.8 \\
\hline 4 & $\begin{array}{l}\text { I am satisfied with the } \\
\text { bonus I received }\end{array}$ & 13 & 7.1 & 33 & 18.0 & 72 & 39.3 & 58 & 31.7 & 7 & 3.8 & 65 & 35.5 \\
\hline 5 & $\begin{array}{l}\text { I am satisfied with the } \\
\text { chances given to me for a } \\
\text { promotion }\end{array}$ & 3 & 1.6 & 16 & 8.7 & 101 & 55.2 & 58 & 31.7 & 5 & 2.7 & 63 & 34.4 \\
\hline 6 & $\begin{array}{l}\text { I am satisfied with the } \\
\text { training provided to me to } \\
\text { learn new skills }\end{array}$ & 3 & 1.6 & 24 & 13.1 & 61 & 33.3 & 73 & 39.9 & 22 & 12.0 & 95 & 51.9 \\
\hline 7 & $\begin{array}{l}\text { I am satisfied with the } \\
\text { benefit packages (e.g., } \\
\text { medical packages, } \\
\text { allowance) provided to me }\end{array}$ & 13 & 7.1 & 34 & 18.6 & 65 & 35.5 & 61 & 33.3 & 10 & 5.5 & 71 & 38.8 \\
\hline
\end{tabular}

Table 1 showed that, within the construct of opportunities and rewards, many respondents are not satisfied with the promotion opportunities, bonuses, salary, and benefits packages they receive. However, many of the respondents are satisfied with their chances for self- 
advancement, training, and recognition. The finding that the respondents are not satisfied with their salaries is consistent with the study of Onukwube (2012), who found that quantity surveyors in Nigeria are not satisfied with their pay. Satisfaction with salary is important because it may impact employees' attitudes and behavior. Employees who feel under-rewarded tend to lose interest in their work at an organization, increasing absenteeism, lateness, and break times, which in turn decrease productivity. Therefore, it is recommended that employers improve their organizations' remuneration schemes.

Table 2 Level of job satisfaction (Construct: nature of work)

\begin{tabular}{|c|c|c|c|c|c|c|c|c|c|c|c|c|c|}
\hline \multirow[t]{2}{*}{$\begin{array}{l}\text { Question } \\
\text { No. }\end{array}$} & \multirow[t]{2}{*}{ Questions } & \multicolumn{2}{|c|}{$\begin{array}{l}\text { Strongly } \\
\text { Disagree }\end{array}$} & \multicolumn{2}{|c|}{ Disagree } & \multicolumn{2}{|c|}{ Neutral } & \multicolumn{2}{|c|}{ Agree } & \multicolumn{2}{|c|}{$\begin{array}{l}\text { Strongly } \\
\text { Agree }\end{array}$} & \multicolumn{2}{|c|}{$\begin{array}{c}\text { Total Agree + } \\
\text { Strongly } \\
\text { Agree }\end{array}$} \\
\hline & & No. & $\%$ & No. & $\%$ & No. & $\%$ & No. & $\%$ & No. & $\%$ & No. & $\%$ \\
\hline 1 & $\begin{array}{l}\text { I am satisfied with the } \\
\text { amount of tasks assigned to } \\
\text { me }\end{array}$ & 3 & 1.6 & 16 & 8.7 & 70 & 38.3 & 84 & 45.9 & 10 & 5.5 & 94 & 51.4 \\
\hline 2 & $\begin{array}{l}\text { I am satisfied with the } \\
\text { opportunities given to me } \\
\text { to perform various tasks }\end{array}$ & 0 & 0.0 & 9 & 4.9 & 56 & 30.6 & 101 & 55.2 & 17 & 9.3 & 118 & 64.5 \\
\hline 3 & $\begin{array}{l}\text { I am satisfied with the } \\
\text { opportunities given to me } \\
\text { to complete the tasks from } \\
\text { the beginning to the end }\end{array}$ & 2 & 1.1 & 7 & 3.8 & 54 & 29.5 & 102 & 55.7 & 18 & 9.8 & 120 & 65.5 \\
\hline 4 & $\begin{array}{l}\text { I am satisfied on the } \\
\text { authority given to me in } \\
\text { making decisions on work } \\
\text { related matters }\end{array}$ & 5 & 2.7 & 14 & 7.7 & 79 & 43.2 & 73 & 39.9 & 12 & 6.6 & 85 & 46.5 \\
\hline 5 & $\begin{array}{l}\text { I am satisfied with the tasks } \\
\text { assigned as it fits to my } \\
\text { abilities }\end{array}$ & 1 & 0.5 & 10 & 5.5 & 51 & 27.9 & 109 & 59.6 & 12 & 6.6 & 121 & 66.2 \\
\hline
\end{tabular}

Table 2 indicated that the respondents are not satisfied with their authority to make decisions. The findings also indicated that, within the construct of nature of work, many of the respondents are satisfied with the tasks they are assigned that fit their abilities, their opportunities to complete tasks from the beginning to the end, their opportunities to perform various types of tasks, and the amount of tasks they are assigned. These findings are similar to those of the study conducted by Onukwube (2012), who found that quantity surveyors in Nigeria are satisfied with the nature of their work. Quantity surveyors are involved in various tasks during the pre-contract and post-contract stages, such as contract administration, tender documentation, and financial tasks. However, the quantity surveyors might prefer to be given an appropriate amount of tasks. This could reduce job stress and increase job satisfaction. It is suggested that employers give staff members authority to make decisions according to the level of their positions.

Table 3 revealed that, within the construct of the working relationship with one's immediate superior, many respondents are satisfied with their immediate superior's technical assistance, constant presence, moral support, and provision of information about work. In addition, most of the respondents are highly satisfied with the fact that their superior has always been tolerant to them. The finding that the respondents are satisfied with moral support and technical assistance is similar to that of the study conducted by Onukwube (2012), who found that quantity surveyors in Nigeria were satisfied with their supervision in terms of the support and guidance related to work matters they received from their superiors. 
Table 3 Level of job satisfaction

(Construct: working relationship with one's immediate superior)

\begin{tabular}{|c|c|c|c|c|c|c|c|c|c|c|c|c|c|}
\hline \multirow{2}{*}{$\begin{array}{l}\text { Question } \\
\text { No. }\end{array}$} & \multirow[t]{2}{*}{ Questions } & \multicolumn{2}{|c|}{$\begin{array}{l}\text { Strongly } \\
\text { Disagree }\end{array}$} & \multicolumn{2}{|c|}{ Disagree } & \multicolumn{2}{|c|}{ Neutral } & \multicolumn{2}{|c|}{ Agree } & \multicolumn{2}{|c|}{$\begin{array}{l}\text { Strongly } \\
\text { Agree }\end{array}$} & \multicolumn{2}{|c|}{$\begin{array}{c}\text { Total Agree + } \\
\text { Strongly Agree }\end{array}$} \\
\hline & & No. & $\%$ & No. & $\%$ & No. & $\%$ & No. & $\%$ & No. & $\%$ & No. & $\%$ \\
\hline 1 & $\begin{array}{l}\text { I am satisfied with the } \\
\text { information about the work } \\
\text { that my superior has given } \\
\text { to me }\end{array}$ & 3 & 1.6 & 9 & 4.9 & 63 & 34.4 & 94 & 51.4 & 14 & 7.7 & 108 & 59.1 \\
\hline 2 & $\begin{array}{l}\text { I am satisfied with the moral } \\
\text { support received from my } \\
\text { superior }\end{array}$ & 4 & 2.2 & 8 & 4.4 & 61 & 33.3 & 89 & 48.6 & 21 & 11.5 & 110 & 60.1 \\
\hline 3 & $\begin{array}{l}\text { I am satisfied with my } \\
\text { superior as he or she is } \\
\text { always around when I have } \\
\text { problems related to work } \\
\text { matters }\end{array}$ & 4 & 2.2 & 10 & 5.5 & 55 & 30.1 & 94 & 51.4 & 20 & 10.9 & 114 & 62.3 \\
\hline 4 & $\begin{array}{l}\text { I am satisfied with my } \\
\text { superior as he or she has } \\
\text { always been tolerant of me }\end{array}$ & 2 & 1.1 & 9 & 4.9 & 47 & 25.7 & 106 & 57.9 & 19 & 10.4 & 125 & 68.3 \\
\hline 5 & $\begin{array}{l}\text { I am satisfied with the } \\
\text { technical assistance that my } \\
\text { superior has given to me }\end{array}$ & 2 & 1.1 & 10 & 5.5 & 55 & 30.1 & 106 & 57.9 & 10 & 5.5 & 116 & 63.4 \\
\hline
\end{tabular}

Also, the finding that the respondents are satisfied with their working relationship with their immediate superiors is consistent with the findings of a study conducted by Yirenkyi-Fianko and Chileshe (2012), who found that construction professionals, including quantity surveyors, are satisfied with their relationship with their supervisors. Superiors' ability to give technical assistance, support, and information about work to their employees may increase employees' job satisfaction.

Table 4 Level of job satisfaction (Construct: organizational factors)

\begin{tabular}{|c|c|c|c|c|c|c|c|c|c|c|c|c|c|}
\hline \multirow{2}{*}{$\begin{array}{l}\text { Question } \\
\text { No. }\end{array}$} & \multirow[t]{2}{*}{ Questions } & \multicolumn{2}{|c|}{$\begin{array}{l}\text { Strongly } \\
\text { Disagree }\end{array}$} & \multicolumn{2}{|c|}{ Disagree } & \multicolumn{2}{|c|}{ Neutral } & \multicolumn{2}{|c|}{ Agree } & \multicolumn{2}{|c|}{$\begin{array}{l}\text { Strongly } \\
\text { Agree }\end{array}$} & \multicolumn{2}{|c|}{$\begin{array}{c}\text { Total Agree + } \\
\text { Strongly Agree }\end{array}$} \\
\hline & & No. & $\%$ & No. & $\%$ & No. & $\%$ & No. & $\%$ & No. & $\%$ & No. & $\%$ \\
\hline 1 & $\begin{array}{l}\text { I am satisfied with the } \\
\text { working culture of the } \\
\text { organization }\end{array}$ & 3 & 1.6 & 15 & 8.2 & 64 & 35.0 & 85 & 46.4 & 16 & 8.7 & 101 & 55.1 \\
\hline 2 & $\begin{array}{l}\text { I am satisfied with the rules } \\
\text { and regulations of the } \\
\text { organization }\end{array}$ & 4 & 2.2 & 22 & 12.0 & 61 & 33.3 & 82 & 44.8 & 14 & 7.7 & 96 & 52.5 \\
\hline 3 & $\begin{array}{l}\text { I am satisfied with the } \\
\text { working hours of the } \\
\text { organization }\end{array}$ & 4 & 2.2 & 17 & 9.3 & 44 & 24.0 & 95 & 51.9 & 23 & 12.6 & 118 & 64.5 \\
\hline 4 & $\begin{array}{l}\text { I am satisfied with the work } \\
\text { space given to me }\end{array}$ & 5 & 2.7 & 10 & 5.5 & 49 & 26.8 & 99 & 54.1 & 20 & 10.9 & 119 & 65.0 \\
\hline 5 & $\begin{array}{l}\text { I am satisfied with facilities } \\
\text { provided by the organization } \\
\text { (e.g., prayer room, pantry) }\end{array}$ & 5 & 2.7 & 20 & 10.9 & 45 & 24.6 & 85 & 46.4 & 28 & 15.3 & 113 & 61.7 \\
\hline
\end{tabular}

Table 4 showed that, within the construct of organizational factors, many of the respondents are satisfied with their organization's work space, working hours, facilities, work culture, and rules and regulations. The results indicated that most employers successfully provided physically conducive working environments to their staff, and these efforts are welcomed by the staff. This is very encouraging.

Table 5 shows that, within the construct of social interaction, most of the respondents are highly satisfied with the communication between them and their colleagues, the support from their 
colleagues, their relationship and cooperation with their colleagues, and the teamwork they practice.

Table 5 Level of job satisfaction (Construct: social interaction)

\begin{tabular}{|c|c|c|c|c|c|c|c|c|c|c|c|c|c|}
\hline \multirow[t]{2}{*}{$\begin{array}{l}\text { Question } \\
\text { No. }\end{array}$} & \multirow[t]{2}{*}{ Questions } & \multicolumn{2}{|c|}{$\begin{array}{l}\text { Strongly } \\
\text { Disagree } \\
\end{array}$} & \multicolumn{2}{|c|}{ Disagree } & \multicolumn{2}{|c|}{ Neutral } & \multicolumn{2}{|c|}{ Agree } & \multicolumn{2}{|c|}{$\begin{array}{c}\text { Strongly } \\
\text { Agree }\end{array}$} & \multicolumn{2}{|c|}{$\begin{array}{c}\text { Total Agree + } \\
\text { Strongly Agree }\end{array}$} \\
\hline & & No. & $\%$ & No. & $\%$ & No. & $\%$ & No. & $\%$ & No. & $\%$ & No. & $\%$ \\
\hline 1 & $\begin{array}{l}\text { I am satisfied with the close } \\
\text { relationship I have with my } \\
\text { colleagues }\end{array}$ & 0 & 0.0 & 3 & 1.6 & 41 & 22.4 & 98 & 53.6 & 41 & 22.4 & 139 & 76.0 \\
\hline 2 & $\begin{array}{l}\text { I am satisfied with the } \\
\text { support that my colleagues } \\
\text { have given to me }\end{array}$ & 0 & 0.0 & 2 & 1.1 & 39 & 21.3 & 108 & 59.0 & 34 & 18.6 & 142 & 77.6 \\
\hline 3 & $\begin{array}{l}\text { I am satisfied that there is } \\
\text { strong cooperation between } \\
\text { my colleagues and me }\end{array}$ & 0 & 0.0 & 6 & 3.3 & 42 & 23.0 & 100 & 54.6 & 35 & 19.1 & 135 & 73.7 \\
\hline 4 & $\begin{array}{l}\text { I am satisfied with the } \\
\text { teamwork practiced by my } \\
\text { colleagues and me }\end{array}$ & 0 & 0.0 & 6 & 3.3 & 47 & 25.7 & 100 & 54.6 & 30 & 16.4 & 130 & 71.0 \\
\hline 5 & $\begin{array}{l}\text { I am satisfied with the } \\
\text { communication between my } \\
\text { colleagues and me }\end{array}$ & 0 & 0.0 & 2 & 1.1 & 38 & 20.8 & 108 & 59.0 & 35 & 19.1 & 143 & 78.1 \\
\hline
\end{tabular}

The finding that the respondents are highly satisfied with their close relationship with colleagues is consistent with the findings of the study conducted by Onukwube (2012), who found that quantity surveyors in Nigeria are satisfied with their relationships with their colleagues. In addition, the finding that the respondents are highly satisfied with the items in the construct of social interaction is similar to the findings of the study conducted by YirenkyiFianko and Chileshe (2012), who found that the construction professionals, including quantity surveyors, are satisfied with their relationship with their workmates. This is because employees who have experienced a friendly workplace find it easier to communicate with their colleagues. When employees have close relationships with their colleagues, they can practice strong cooperation and teamwork. A close relationship with colleagues could also increase employees' job satisfaction because colleagues can act as a support system for employees; whenever employees have problems related to work, they can immediately share those problems with their colleagues.

Table 6 Level of job satisfaction (Construct: attitude towards work)

\begin{tabular}{|c|c|c|c|c|c|c|c|c|c|c|c|c|c|}
\hline \multirow{2}{*}{$\begin{array}{l}\text { Question } \\
\text { No. }\end{array}$} & \multirow[t]{2}{*}{ Questions } & \multicolumn{2}{|c|}{$\begin{array}{l}\text { Strongly } \\
\text { Disagree }\end{array}$} & \multicolumn{2}{|c|}{ Disagree } & \multicolumn{2}{|c|}{ Neutral } & \multicolumn{2}{|c|}{ Agree } & \multicolumn{2}{|c|}{$\begin{array}{l}\text { Strongly } \\
\text { Agree }\end{array}$} & \multicolumn{2}{|c|}{$\begin{array}{c}\text { Total Agree + } \\
\text { Strongly Agree }\end{array}$} \\
\hline & & No. & $\%$ & No. & $\%$ & No. & $\%$ & No. & $\%$ & No. & $\%$ & No. & $\%$ \\
\hline 1 & $\begin{array}{l}\text { I work hard to perform } \\
\text { tasks assigned to me }\end{array}$ & 0 & 0.0 & 1 & 0.5 & 44 & 24.0 & 113 & 61.7 & 25 & 13.7 & 138 & 75.4 \\
\hline 2 & $\begin{array}{l}\text { I always try to complete } \\
\text { tasks assigned to me } \\
\text { within the allocated time }\end{array}$ & 0 & 0.0 & 2 & 1.1 & 27 & 14.8 & 116 & 63.4 & 38 & 20.8 & 154 & 84.2 \\
\hline 3 & $\begin{array}{l}\text { I always happily accept } \\
\text { tasks assigned to me }\end{array}$ & 2 & 1.1 & 8 & 4.4 & 67 & 36.6 & 90 & 49.2 & 16 & 8.7 & 106 & 57.9 \\
\hline 4 & $\begin{array}{l}\text { I always make suggestions } \\
\text { to my organization for } \\
\text { improvement in work- } \\
\text { related matters }\end{array}$ & 3 & 1.6 & 17 & 9.3 & 73 & 39.9 & 77 & 42.1 & 13 & 7.1 & 90 & 49.2 \\
\hline 5 & $\begin{array}{l}\text { I always attempt to } \\
\text { produce high-quality work }\end{array}$ & 0 & 0.0 & 1 & 0.5 & 26 & 14.2 & 124 & 67.8 & 32 & 17.5 & 156 & 85.3 \\
\hline
\end{tabular}


Table 6 indicates that the respondents do not always make suggestions for the organization to improve. The findings also indicate that, within the construct of attitude towards work, many of the respondents happily accept tasks assigned to them and most of the respondents believe they always attempt to produce high-quality work, try to complete assigned tasks within the allocated time, and always work hard to perform the tasks assigned to them.

\section{CONCLUSION}

This study finds that $38.8 \%$ of respondents intend to quit their current organizations. This percentage is high and impacts the firms' staff stability. Turnover intention might be related to job dissatisfaction. According to the data, the majority of respondents are not satisfied with most of the items tested in the constructs of opportunities and rewards, specifically the salary, bonuses, benefits, and promotion opportunities provided by the firms. In addition, the majority of respondents expressed their dissatisfaction with the opportunities provided by their firms to participate in making work-related decisions and suggestions. The findings of this study imply the need of quantity surveying firms in Malaysia to formulate certain strategies to enhance job satisfaction of their staff which is having a positive impacts towards the fiirms' staff stability.

\section{REFERENCES}

Alam, M.M., Mohammad, J.F., 2010. Level of Job Satisfaction and Intent to Leave Among Malaysian Nurses. Business Intelligence Journal, Volume 3(1), pp. 123-137

Alam, S.M.T., 2012. Factors Affecting Job Satisfaction, Motivation and Turnover Rate of Medical Promotion Officer (MPO) in Pharmaceutical Industry: A Study Based in Khulna City. Asian Business Review, Volume 1(2), pp. 126-131

Ali, N., 2008. Factors Affecting Overall Job Satisfaction and Turnover Intention. Journal of Managerial Sciences, Volume 2(2), pp. 239-252

Arham, A., Abdulquadri, A.B., Enegbuma, W.I., Ajagbe, A.M., Kherun, N.A., 2011. Evaluation of Job Satisfaction and Performance of Employees in Small and Medium Sized Construction Firms in Nigeria. $2^{\text {nd }}$ International Conference on Construction and Project Management (IPERDR), Volume 15, pp. 225-229

Aydogdu, S., Asikgil, B., 2011. An Empirical Study of the Relationship among Job Satisfaction, Organizational Commitment and Turnover Intention. International Review of Management and Marketing, Volume 1(3), pp. 43-53

Chatzoglou, P.D., Vraimaki, E., Komsiou, E., Polychrou, E., Diamantidis, A.D., 2011. Factors Affecting Accountants' Job Satisfaction and Turnover Intentions: A Structural Equation Model. In: Proceeding of the $8^{\text {th }}$ International Conference on Enterprise Systems, Accounting and Logistics, Thassos Island, Greece. pp. 130-147

Gamage, P.N., Buddhika, K.D.M., 2013. Job Satisfaction and Intention to Leave of IT Professionals in Sri Lanka. Asia Pacific Journal of Marketing \& Management Review, Volume 2(9), pp. 1-11

Ghayyur, M., Jamal, W., 2012. Work-Family Conflicts: A Case of Employees' Turnover Intention. International Journal of Social Science and Humanity, Volume 2(3), pp. 168174

Gillet, N., Gagne, M., Sauvagère, S., Fouquereau, E., 2012. The Role of Supervisor Autonomy Support, Organizational Support, and Autonomous and Controlled Motivation in Predicting Employees' Satisfaction and Turnover Intentions. European Journal of Work and Organizational Psychology, Volume 22(4), pp. 450-460

Glissmeyer, M., Bishop J.W., Fass, R.D., 2008. Role Conflict, Role Ambiguity and Intention to Quit the Organization: The Case of Law Enforcement. Academy of Management Journal, Volume 40(1), pp. 82-111 
Habib, A., Khurseed, A., Idrees, A.S., 2010. Relationship between Job Satisfaction, Job Performance Attitude towards Work and Organizational Commitment. European Journal of Social Sciences, Volume 18(2), pp. 257-267

Hee, C.H.S., Ling, F.Y.Y., 2011. Strategies for Reducing Employee Turnover and Increasing Retention Rates of Quantity Surveyors. Construction Management and Economics, Volume 29(10), pp. 1059-1072

Mahdi, A.F, M., Zin, M.Z.M., Nor, M.R.M., Sakat, A.A., Naim, A.B.A., 2012. The Relationship between Job Satisfaction and Turnover Intention. American Journal of Applied Sciences, Volume 9(9), pp. 1518-1526

Martin, J., 2010. Key Concepts in Human Resources Management. California: Sage Publications Inc.

Mathis, R.L., Jackson, J.H., 2002. Human Resource Management: Essential Perspective. Mason: South-Western Thomson Learning

Matz, A.K., Wells, J.B., Minor, K.I., Angel, E., 2013. Predictors of Turnover Intention among Staff in Juvenile Correctional Facilities. Youth Violence and Juvenile Justice, Volume 11(2), pp. 115-131

Mbah, S.E., Ikemefuna, C.O., 2012. Job Satisfaction and Employees' Turnover Intentions in Total Nigeria Plc. in Lagos State. International Journal of Humanities and Social Science, Volume 2(14), pp. 275-287

Nankervis, A., Compton, R., Baird, M., 2005. Human Resources Management Strategies and Processes. $5^{\text {th }}$ Edition. Victoria: Thomson Learning Australia

Nkado, R., Meyer, T., 2001. Competencies of Professional Quantity Surveyors: A South African Perspective. Construction Management and Economics, Volume 19(5), pp. 481491

Onukwube, H.N., 2012. Correlates of Job Satisfaction amongst Quantity Surveyors in Consulting Firms in Lagos, Nigeria. Australasian Journal of Construction Economics and Building, Volume 12(2), pp. 43-54

Puvada, D.D., Rao, G.V., 2012. Performance and Job Satisfaction: A Critical Analysis. Business Administration and Business Economics (AUDOE), Volume 8(2), pp. 5-17

Rabie, M., Riad, H., 2011. Quantity Surveying Role in Construction Projects - A Comparison of Roles in Sweden and the UK, Bachelor Thesis, Malmo University

Rahman, A., Naqvi, S.M.M.R, Ramay, M.I., 2008. Measuring Turnover Intention: A Study of IT Professionals in Pakistan. Measuring Turnover Intention: A Study of IT Professionals in Pakistan. International Review of Business Research Papers, Volume 4(3), pp. 45-55

Randhawa, G., 2007. Relationship between Job Satisfaction and Turnover Intentions: An Empirical Analysis. Indian Management Studies Journal, Volume 11, pp. 149-159

Rizwan, M., Mukhtar, A., 2014. Employee Satisfaction and Turnover Intention. International Journal of Human Resource Studies, Volume 4(3), pp. 87-106

Saeed, S., Waseem, M., Sikander, S., Rizwan, M., 2014. The Relationship of Turnover Intention with Job Satisfaction, Job Performance, Leader Member Exchange, Emotional Intelligence and Organizational Commitment. International Journal of Learning \& Development, Volume 4(2), pp. 242-256

Salleh, R., Nair, M.S., Harun, H., 2012. Job Satisfaction, Organizational Commitment, and Turnover Intention: A Case Study on Employees of a Retail Company in Malaysia. World Academy of Science, Engineering and Technology, Volume 6(12), pp. 3429-3426

Samad, S., 2006. The Contribution of Demographic Variables: Job Characteristics and Job Satisfaction on Turnover Intentions. Journal of International Management Studies, Volume 1(1), pp. 1-12

Stone, R.J., 2008. Human Resources Management. $6^{\text {th }}$ Edition. Queensland: John Wiley \& Sons Australia Ltd 
Sun, K., 2011. The Turnover Intentions for Construction Engineers. Journal of Marine Science and Technology, Volume 19(5), pp. 550-556

Tett, R.P., Meyer, J.P., 1993. Job Satisfaction, Organizational Commitment, Turnover Intention and Turnover: Path Analyses based on Meta-analytic Findings. Personnel Psychology, Volume 46(2), pp. 259-293

Tnay, E., Othman, A.E.A., Siong, H.C., Lim, S.L.O., 2013. The Influences of Job Satisfaction and Organizational Commitment on Turnover Intention. The $9^{\text {th }}$ International Conference on Cognitive Science, Procedia - Social and Behavioral Sciences, Volume 97, pp. 201208

Ucho, A., Terseer, M.,, Onyishi, I.E., 2012. Job Satisfaction, Gender, Tenure, and Turnover Intentions among Civil Servants in Benue State. Interdisciplinary Journal of Contemporary Research in Business, Volume 3(11), pp. 378-387

Wolf, M.G., 1970. Need Gratification Theory: A Theoretical Reformulation of Job Satisfaction/ Dissatisfaction and Job Motivation. Journal of Applied Psychology, Volume 54, pp. 87-94

Yirenkyi-Fianko, A.B., Chileshe N., 2012. Job Satisfaction of Professionals within the Ghanaian Construction Industry. In Smith, S.D. (Ed.) In: Proceedings of the $28^{\text {th }}$ Annual ARCOM Conference, Association of Researchers in Construction Management, University of Edinburgh, Edinburgh, pp. 589-599

Yucel, I., 2012. Examining the Relationships among Job Satisfaction, Organizational Commitment, and Turnover Intention: An Empirical Study. International Journal of Business and Management, Volume 7(20), pp. 44-58 